\title{
非軸対称衝突噴霧の蒸発過程の二波長レーザ吸収散乱法による解析*
}

\author{
佐藤圭 峰*1, 田所正 ${ }^{* 2}$, 高剣*3 \\ 松 本 有 平*1, 西田恵哉*1, 山川正尚*2
}

\section{Analysis of Evaporation Process of Non-Axisymmetric Wall-Impinging Spray by Means of Laser Absorption Scattering Technique}

\author{
Kiyotaka SATO*4, Tadashi TADOKORO, Jian GAO, \\ Yuhei MATSUMOTO, Keiya NISHIDA and Masahisa YAMAKAWA \\ ${ }^{* 4}$ Department of Mechanical System Engineering, University of Hiroshima, \\ 1-4-1 Kagamiyama, Higashihiroshima-shi, Hiroshima, 739-8527 Japan
}

\begin{abstract}
An evaporation process plays an important role on the combustion and emission formation processes in a direct injection (D. I.) gasoline engines. An experimental study was conducted on the evaporation process of the non-axisymmetric wall-impinging spray injected by the hole type injector for a D. I. gasoline engine. For the quantitative measurement of the vapor of the non-axisymmetric spray, the image processing technique using the Laser Absorption Scattering (LAS) principle was newly developed. The total amount of fuel vapor in the whole spray was obtained from the optical thickness image of the vapor and the Lambert Beer's law. The amount of fuel vapor in the wallimpinging spray is decreased compared with the free spray. In addition, the amount of fuel vapor is decreased as the distance between nozzle tip and the impingement wall is decreased.
\end{abstract}

Key Words : Gasoline Engine, Fuel Injection, Atomization, Laser-aided Diagnostics

\section{1. 緒言}

近年，低環境負荷化や省エネルギー化が緊急の課題 とされている中，ガソリン機関においては，直噴化に よる環境性能向上が顕著である. 従来, 直噴ガソリン エンジンの燃料供給には, 雰囲気圧力の増加に伴い噴 霧角が狭まるスワールインジェクタが用いられてきた が，このような雾囲気密度の変化による噴霧構造の変 化が少なく，燃焼室内での噴霧配置の自由度が高い木 一ルノズルの利用が検討されている(1) (6).

直噴ガソリンエンジンの燃焼形態は，吸気行程に燃 料を噴射し均質な混合気を作った後に点火する均質燃 焼と, 圧縮行程後半に燃料を噴射し, 点火プラグ周辺 に混合気を集めて点火する成層燃焼に分けられるる(7) (9). 成層燃焼の特徵として低負荷時の燃費を向上できる反 面, 混合気形成が難しく，エミッションの低減が課題 である.また，狭い燃焼室内に燃料を噴射するため， ピストンやシリンダライナへの燃料噴霧の衝突は避け られないと考えられる.

著者らは，紫外光と可視光を光源とした二波長レ一

* 原稿受付 2007 年 12 月 10 日，

*1 正員, 広島大学大学院工学研究科(百739-8527 東広島市鏡 山 1-4-1).

*2ママツダ(株)パワートレイン技術開発部(亚730-8670 広島県 安芸郡府中町新地 3-1)

*3 広島大学大学院工学研究科.

E-mail : sato-kiyo@hiroshima-u.ac.jp
ザ吸収散乱（Laser Absorption Scattering：LAS）法を用 いて, 直噴ガソリン噴霧についての種々の研究を行っ てきたが，それらはいずれも軸対称の自由噴霧につい ての解析であった ${ }^{(10) \sim(12)}$. 本研究では, 非軸対称噴霧解 析を行う LAS 法を新たに開発し, 非軸対称の壁面衝突 噴霧に応用した. 高温高圧の定容容器内で, 圧縮行程 後期における噴射で然料噴霧がピストン壁面に衝突す る様子を模擬した壁面衝突噴霧の LAS 解析を行い, 壁 面衝突が燃料の蒸発に与える影響を調べた.

\section{LAS 法の原理}

2-1 LAS 法の計測原理 LAS 法とは二種類の波 長のレーザを燃料噴霧に照射して, 噴霧を通過する際 のそれぞれの波長の光の減衰から, 噴霧の蒸気相およ び夜相の濃度を求める方法である。

図 1 は燃料が吸収する波長 $\lambda_{A}$ およひ吸収しない波長 $\lambda_{T}$ の入射光が蒸発噴霧を通過する際に減衰される過程 を示している. 強度 $I_{0}$ の入射光は噴霧を通過する際に， 蒸気相の吸収および夜相（液滴群）の散乱と吸収で減 衰し, 強度 $I_{t}$ の透過光になる. 波長 $\lambda_{A}$ の透過光減衰率 $\log \left(I_{d} I_{d}\right)_{2 A}$ は液相の散乱と吸収による透過光減衰率 $\log \left(I_{d} I I_{\text {Lsca }}, \log \left(I_{d} I_{I_{I}}\right)_{\text {Labs }}\right.$ および蒸気相燃料の吸収による 透過光減衰率 $\log \left(I_{d} I I_{V}\right)_{\text {vabs }}$ によって式 (1) のように表す ことができる.また, 波長 $\lambda_{T}$ の透過光減衰率 


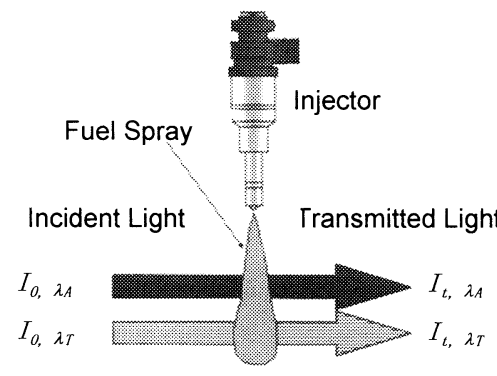

Fig. 1 Principle of LAS technique

$\log \left(I_{\delta} I_{\nu}\right)_{\lambda T}$ は, 液相の散乱による透過光減衰率 $\log \left(I_{d} / I_{\nu}\right)_{L s c a}$ によって式 (2) のように表すことができる.

$$
\begin{aligned}
& \log \left(\frac{I_{0}}{I_{t}}\right)_{\lambda_{A}}=\log \left(\frac{I_{0}}{I_{t}}\right)_{\text {Lsca }+ \text { Labs }}-\log \left(\frac{I_{0}}{I_{t}}\right)_{\text {Vabs }} \\
& \log \left(\frac{I_{0}}{I_{t}}\right)_{\lambda_{T}}=\log \left(\frac{I_{0}}{I_{t}}\right)_{\text {Lsca }}
\end{aligned}
$$

式（1）の右辺第 1 項にある液滴の吸収による透過光 減衰率 $\log \left(I_{\delta} / I_{l}\right)_{l a b s}$ が無視できる程度に小さいこと(10), また両波長の液滴の散乱による透過光減衰率 $\log \left(I_{d} I_{\nu}\right)_{\text {ssca }}$ は同等であることが確認されている(10)ため, 蒸気相の吸収による透過光減衰率 $\log \left(I_{d} / I_{\nu}\right)_{\text {Vabs }}$ と, 液滴 の散乱による透過光減衰率 $\log \left(I_{\delta} / I_{\nu}\right)_{\text {Lsca }}$ は, それぞれ式

（3）と式（4）のように表すことができる.

$$
\begin{aligned}
& \log \left(\frac{I_{0}}{I_{t}}\right)_{\text {Vabs }}=\log \left(\frac{I_{0}}{I_{t}}\right)_{i_{A}}-\log \left(\frac{I_{0}}{I_{t}}\right)_{i_{T}} \\
& \log \left(\frac{I_{0}}{I_{t}}\right)_{L s c a}=\log \left(\frac{I_{0}}{I_{t}}\right)_{\lambda_{T}}
\end{aligned}
$$

軸対称噴霧に対しては玉ねぎの皮むきモデル(13)適用 することで，断面内の当量比分布を求めている.

LAS 法試験燃料として, 動粘度, 表面張力, 沸点な どの物性值がガソリンに近いパラキシレンを使用した。 図 2 の液相然料の吸収スペクトルに示すように, パラ キシレンは紫外光を強く吸収し，可視光を吸収しない という特性を持っているため ${ }^{(10)}, \mathrm{Nd}: \mathrm{YAG}$ レーザの第 四高調波（波長 $266 \mathrm{~nm}$ の紫外光）を $\lambda_{A}$ の光源に，第二 高調波 (波長 $532 \mathrm{~nm}$ の可視光) を $\lambda_{T}$ の光源に使用した.

$2 \cdot 2$ 非軸対称噴霧への応用 非軸対称噴霧に対 しては玉ねぎの皮むきモデルを適用できず，断面の当 量比分布を求めることができない.しかし，蒸気相の 吸収による透過光減衰率 $\log \left(I_{\delta} / I_{\nu}\right)_{\text {Vabs }}$ を光路方向に積分 することで, 光路中に存在する蒸気相質量を求めるこ とができる. 図 3 に示すように, 蒸気相濃度 $C_{v}\left[\mathrm{~kg} / \mathrm{m}^{3}\right]$

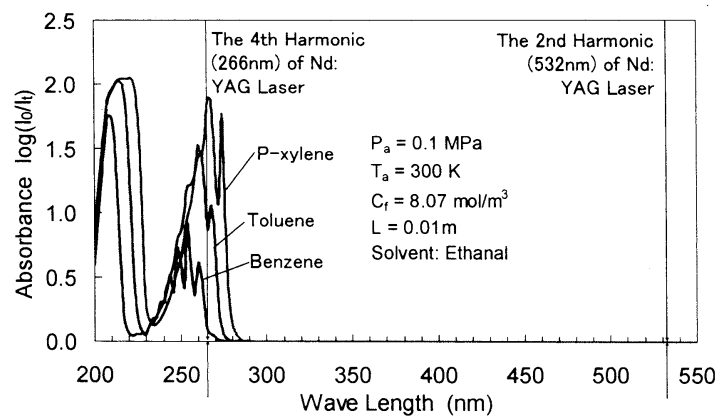

Fig. 2 Absorption spectra of liquid phase candidate fuels

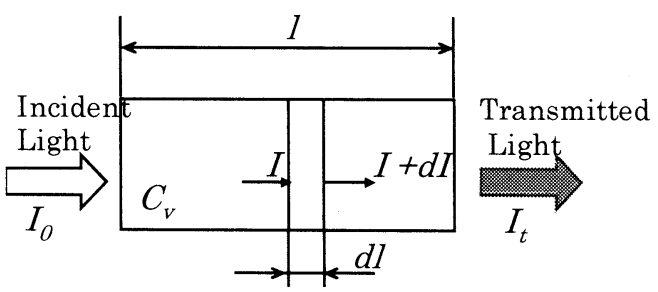

Fig. 3 Lambert-Beer's law

の光路長 $l$ の領域に対して, 入射強度 $I_{0}$ のレーザ光が 蒸気相の吸収により減衰され強度 $I_{t}$ になるとする.こ の時, 光路中の微小長さ $d l$ の領域の蒸気相による透過 光減衰率は以下の式（5）で表すことができる.

$$
\begin{gathered}
\log \left(\frac{I}{I+d I}\right)_{\text {Vabs }}=\frac{\varepsilon}{M W} \cdot C_{V} \times 10^{2} d l \\
C_{V}: \text { 蒸気相濃度 }\left[\mathrm{kg} / \mathrm{m}^{3}\right] \\
l: \text { 光路長 }[\mathrm{m}] \\
\varepsilon: \text { モル吸光係数 }[\mathrm{litter} /(\mathrm{mol} \cdot \mathrm{cm})] \\
M W \text { : 分子量 }[\mathrm{kg} / \mathrm{kmol}]
\end{gathered}
$$

式 (5) を光路方向に積分することにより, 光路の単 位断面積当たりの蒸気相質量の積算値 $\overline{C_{V}}\left[\mathrm{~kg} / \mathrm{m}^{2}\right]$ を 式（6）のように示すことができる.

$$
\begin{aligned}
\overline{C_{V}}=\int_{l} C_{V} d l & =\frac{M W}{\varepsilon} \int_{l} \log \left(\frac{I}{I+d I}\right)_{\text {Vabs }} d l \\
& =\frac{M W \cdot \log \left(I_{0} / I_{t}\right)_{\text {Vabs }}}{\varepsilon}
\end{aligned}
$$

$\overline{C_{V}}$ : 光路の単位断面積当たりの蒸気相質量の 積算値 $\left[\mathrm{kg} / \mathrm{m}^{2}\right]$

この時，モル吸光係数と分子量は光路長方向におい て一定であると仮定している.モル吸光係数は図 4 に 示すように温度に依存する ${ }^{(10)}$. 図 4 は実験により求め た圧力 $1.0 \mathrm{MPa}$ におけるモル吸光係数で，温度が低下 すると増大する．噴霧内での燃料蒸発による噴霧内の 温度低下は，これまでの軸対称自由噴霧の LAS 計測結 果を参考にすると, 最大で約 $40^{\circ} \mathrm{C}$ 程度であるので，モ 


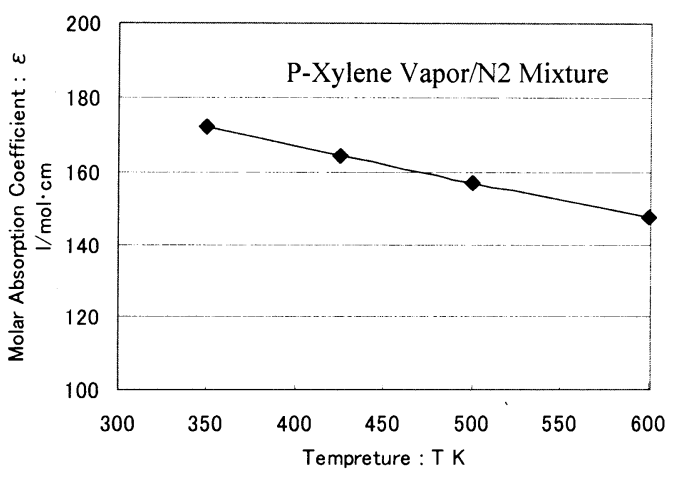

Fig. 4 Temperature dependency of molar absorption coefficient of $\mathrm{p}$-xylene vapor and N2 mixture $(\mathrm{P}=1.0 \mathrm{MPa})$

ル吸光係数の変化は最大で $2 \%$ 程度となり, 蒸気相質 量の変化も $2 \%$ 程度となる. 従って, 蒸気相質量を求 める過程において，モル吸光係数は一定と仮定できる と判断した，そして，平均蒸気濃度を噴霧領域全体 $\mathrm{S}$ において積分を行うと, 式 (7) のように燃料噴霧中の 蒸気相質量 $M_{V}[\mathrm{mg}]$ を求めることができる.

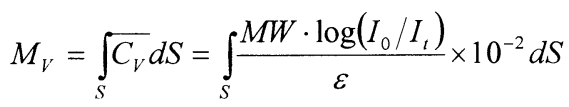

\section{$M_{v}:$ 燃料噴霧中の蒸気相質量 $[\mathrm{mg}]$}

\section{3. 実験装置}

図 5 に LAS 法の実験装置の概略図を示す. 光源に使 用した Nd：YAG レーザは，第二高調波 $(532 \mathrm{~nm})$ の 可視光と第四高調波 $(266 \mathrm{~nm})$ の紫外光を同時に発振 させることが可能である. それらの 2 つのビームはダ イクロイックミラーによって一度可視光と紫外光に分 離され，それぞれデフューザ等によって強度が調整さ れた後，ビームエクスパンダによってビーム径が拡大 される. その後, 可視光と紫外光のビームは, 八ーモ ニックセパレータによって再び合成され，高温高圧容 器内に照射される. 可視光と紫外光のビームは，それ ぞれ燃料液滴の散乱と燃料蒸気相の吸収によって減衰 を受けながら容器内を通過し, 再度ハーモニックセパ レータによって可視光と紫外光のビームに分離され， 可視光用と紫外光用の CCD カメラに取り込まれ, コン ピュータに送られる.

圧力容器内部のガスは容器内部に設置した円筒熱板 により高温に，また窒素ボンべを用いて加圧すること が可能である.インジェクタには窒素で加圧したアキ ユムレータを用いて然料であるパラキシレンを供給し， インジェクタドライバにより噴射を制御した.レーザ,

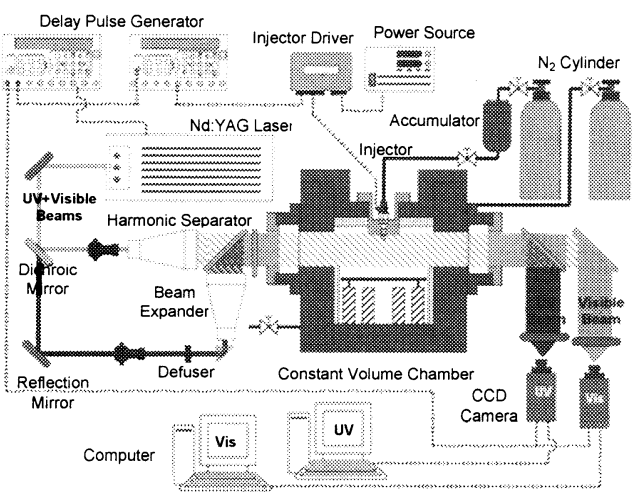

Fig. 5 Experimental apparatus of LAS

CCD カメラおよび然料噴射は2 台のディレイパルスジ エネレータから発信する信号を用いて制御した。

\section{4. 実験結果}

表 1 に実験条件を示す。䨌囲気条件は実際の直噴力゙ ソリン機関における圧縮行程噴射を想定し, 温度 $\mathrm{T}_{\mathrm{a}}=500 \mathrm{~K}$, 圧力 $\mathrm{P}_{\mathrm{a}}=1.0 \mathrm{MPa}$ とした. 噴射圧力を $15 \mathrm{MPa}$, 噴射量を $1.6 \mathrm{mg}$ 一定とした. インジェクタはノズル先 端にサック室が無い VCO (Valve Covered Orifice) タイ プの単噴孔ホールノズルを用いた，図 6 に示すように 平板は噴孔軸との角度を $\theta_{\mathrm{imp}}=60^{\circ}$ とし, 噴孔軸に沿っ たノズル先端から平板までの距離を $\mathrm{D}_{\mathrm{imp}}=15,30,45$, $60 \mathrm{~mm}$ と変化させた.

Table 1 Experimental conditions

\begin{tabular}{|c|c|}
\hline \multicolumn{2}{|c|}{ Ambient Gas } \\
\hline Ambient $\mathrm{Gas}$ & Nitrogen \\
\hline Temperature $: \mathrm{T}_{\mathrm{a}}[\mathrm{K}]$ & 500 \\
\hline Pressure $: \mathrm{P}_{\mathrm{a}}[\mathrm{MPa}]$ & 1.0 \\
\hline
\end{tabular}

\begin{tabular}{|c|c|}
\hline \multicolumn{2}{|c|}{ Fuel Injection } \\
\hline Fuel & P-xylene \\
\hline Injector & Hole Type \\
\hline Hole Diameter [mm] & 0.15 \\
\hline L/D & 2 \\
\hline Injection Duration [ms] & 1.1 \\
\hline Injection Pressure [MPa] & 15 \\
\hline Injection Quantity [mg] & 1.6 \\
\hline
\end{tabular}

\begin{tabular}{|c|c|}
\hline \multicolumn{2}{|c|}{ Impingement Wall } \\
\hline Distance $: \mathrm{D}_{\text {imp }}[\mathrm{mm}]$ & $15,30,45,60$ \\
\hline Angle $: \theta_{\text {imp }}[\mathrm{deg}]$. & 60 \\
\hline
\end{tabular}

\section{5. 実験結果および考察}

$5 \cdot 1$ 計測精度 図 7 に単噴孔ホールノズルから 噴射した，軸対称と見なせる噴霧を対象とした非軸対 称噴霧用 LAS 法による蒸気相質量の結果と, 従来の軸 対称噴霧用 LAS 法による蒸気相質量の比較を示す. 両 者の差は最大 $13 \%$ である，非軸対称噴霧用 LAS 法で 


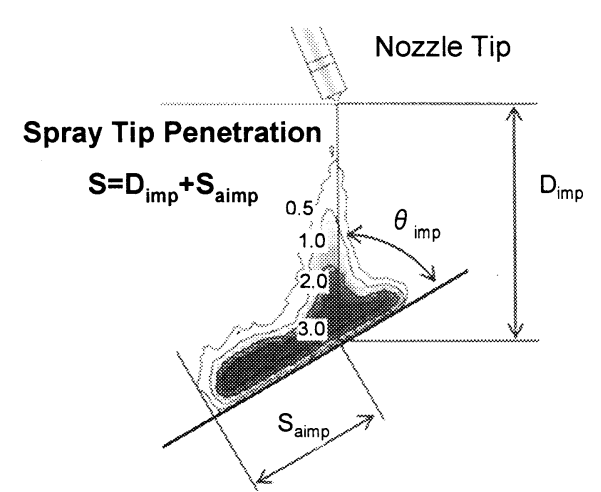

Fig. 6 Spray tip penetration of wall impinging spray

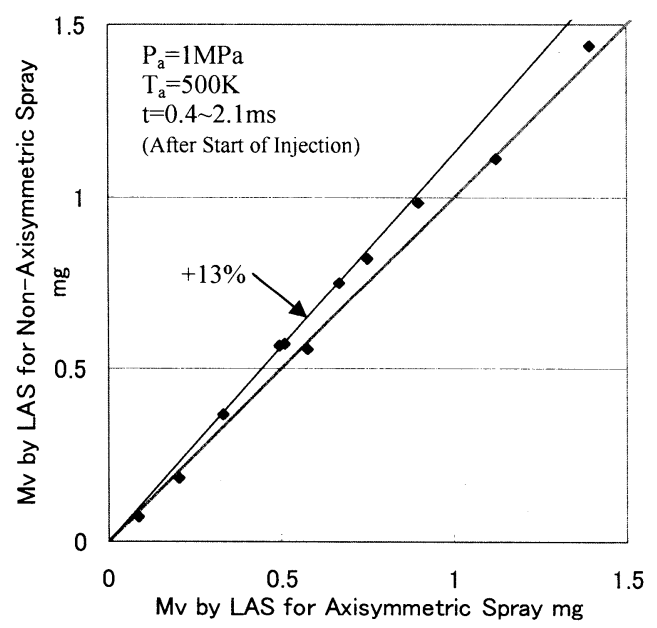

Fig. 7 Difference in total mass of vapor in completely evaporated spray obtained by LAS axisymmtric spray and LAS for non-axisymmtric spray

は噴霧の光路長内の温度は一定であると仮定している. 5.4 節で述べたように実際の噴霧内の温度は雰囲気温

度より低い.しかし解析では噴霧内温度を雰囲気温 度としているため，小さいモル吸光係数が使用されて いる. その結果，蒸気相質量が過大評価されたと考え られる. また軸対称と見なせる完全蒸発噴霧の LAS 解 析の結果から求めた蒸気相質量と噴射量を比較するこ とで, 軸対称噴霧用 LAS 法の蒸気相質量の計測精度は 約 $15 \%$ であることが分かっている(10). 従って，新たに 開発した非軸対称噴霧用 LAS 法は蒸気相質量を解析 するのに十分な精度であると言える.

\section{$5 \cdot 2$ 光路長方向の積算燃料蒸気相質量の分布} 図 8 に壁面衝突噴霧（衝突距離 $\mathrm{D}_{\mathrm{imp}}=15,30,45 \mathrm{~mm}$ ）お よび自由噴霧（平板無し）の燃料蒸気相質量分布（光 路長方向積算・単位面積当たり）を示す. 撮影タイミ ングは，噴射終了時間（EOI: End of Injection）を基準に $0.5 \mathrm{~ms}$ 刻みで定めた。
衝突噴霧の場合，噴霧が壁面に衝突後，壁面に 沿って左右に薄く拡がりながら蒸発し, 時間の経 過とともに幅の厚い蒸気塊を形成していく様子が 分かる.また噴孔軸の左側（衝突角度が大きい側） に蒸気が拡がりやすく, 噴霧先端到達距離が長く なっていることが分かる.

自由噴霧および衝突距離 $\mathrm{D}_{\mathrm{imp}}=45 \mathrm{~mm}$ の場合, 蒸 気相質量の光路長方向積算値が最大で $5.0 \times 10^{-3} \mathrm{~kg} / \mathrm{m}^{2}$ 以上あるのに対し， $\mathrm{D}_{\mathrm{imp}}=30 \mathrm{~mm}$ では 最大 $4.0 \times 10^{-3} \mathrm{~kg} / \mathrm{m}^{2}$ 程度, $D_{\mathrm{imp}}=15 \mathrm{~mm}$ では最大 $2.7 \times 10^{-3} \mathrm{~kg} / \mathrm{m}^{2}$ 程度であり, 衝突距離が短いほど然 料蒸気相質量の大きい領域が少なくなっている. また壁面近傍の燃料蒸気相質量分布を見ると，壁 面に近いほど值が小さくなっている。これは壁面 上の燃料液膜の形成により，蒸発が抑えられてい るものと考えられる.

一方，自由噴霧を見ると，噴霧後端から先端ま での中間付近では噴孔軸より左側に蒸気相質量の 大きい領域が存在し, 噴霧先端では右側に存在し ている。すなおち噴霧が噴孔軸方向に蛇行した非 軸対称の形状をしている。このような分布は，従 来の研究(9) (11)におけるサック室のあるホールノ ズルでは観察されなかった。本研究で使用した $\mathrm{VCO}$ ノズルの特徴として, ニードル上昇中のノズ ル内噴孔入口付近の流動の非軸対称性が噴霧形状 に影響を与えているものと推測される.

\section{$5 \cdot 3$ 噴霧先端到達距離図 9 に図 8 の燃料蒸} 気相質量分布から求めた壁面衝突噴霧および自由 噴霧の先端到達距離を示す. 噴霧先端到達距離は, 図 6 に示すように壁面に衝突する前の自由噴霧の 期間 (before WI: Wall Impingement, 黒シンボル) と, 壁面に衝突した後の壁面に沿って噴霧が発達 していく期間（after WI，白シンボル）に分けて定 義した。また LAS 法による Optical 画像や蒸気相 および液相質量分布から蒸気相先端到達距離と液 相先端到達距離を比較した場合，蒸気相先端到達 距離 $($ or $\geqq)$ 液相先端到達距離となるため, 蒸気 相先端到達距離を噴霧先端到達距離とした。自由 噴霧の期間は，噴孔軸に沿って噴霧先端の平均蒸 気相濃度 $\overline{C_{v}}>0.5 \times 10^{-3} \mathrm{~kg} / \mathrm{m}^{2}$ の領域までの距離で定 義し, 壁面衝突後は衝突距離 $\mathrm{D}_{\mathrm{imp}}$ と噴孔軸と壁面 が交差する位置から壁面に沿って左側の $\overline{C_{v}}>0.5 \times 10^{-3} \mathrm{~kg} / \mathrm{m}^{2}$ までの距離 $\mathrm{S}_{\mathrm{imp}}$ との和で定義し た.

衝突距離 $\mathrm{D}_{\mathrm{imp}}=15,30 \mathrm{~mm}$ の結果を見ると, 衝突後は, 噴霧先端到達距離の勾配すなわち噴霧先端到達速度が 


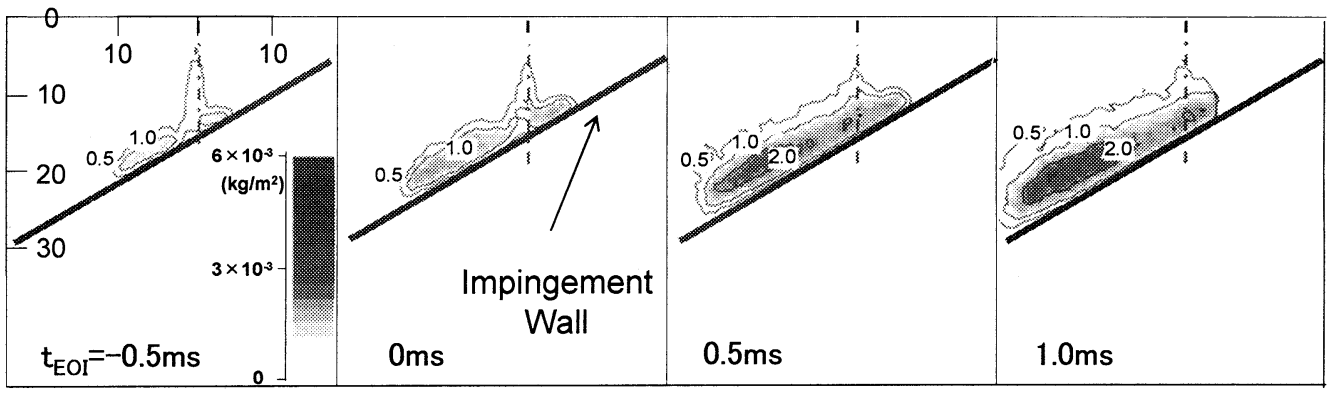

(a) $\mathrm{D}_{\text {imp }}=15 \mathrm{~mm}, \theta_{\text {imp }}=60^{\circ}$

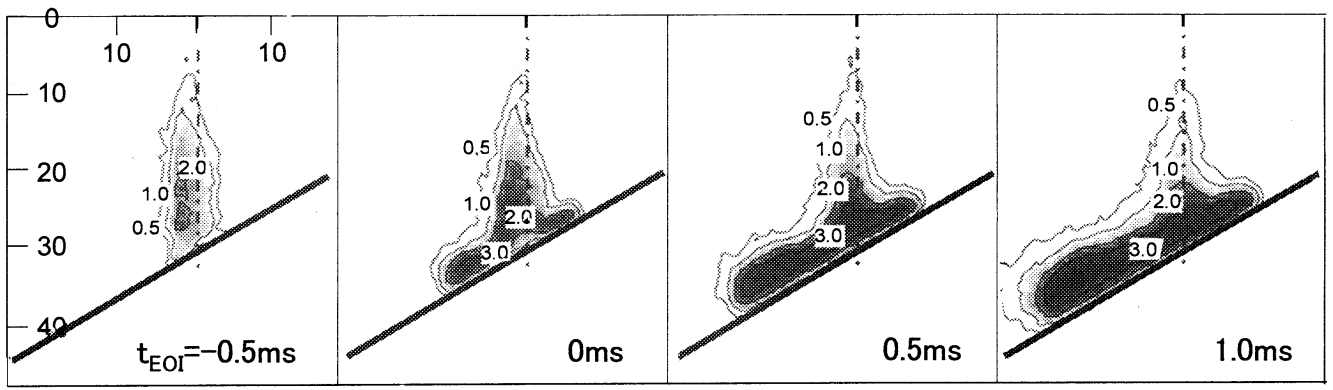

(b) $\mathrm{D}_{\text {imp }}=30 \mathrm{~mm}, \theta_{\text {imp }}=60^{\circ}$

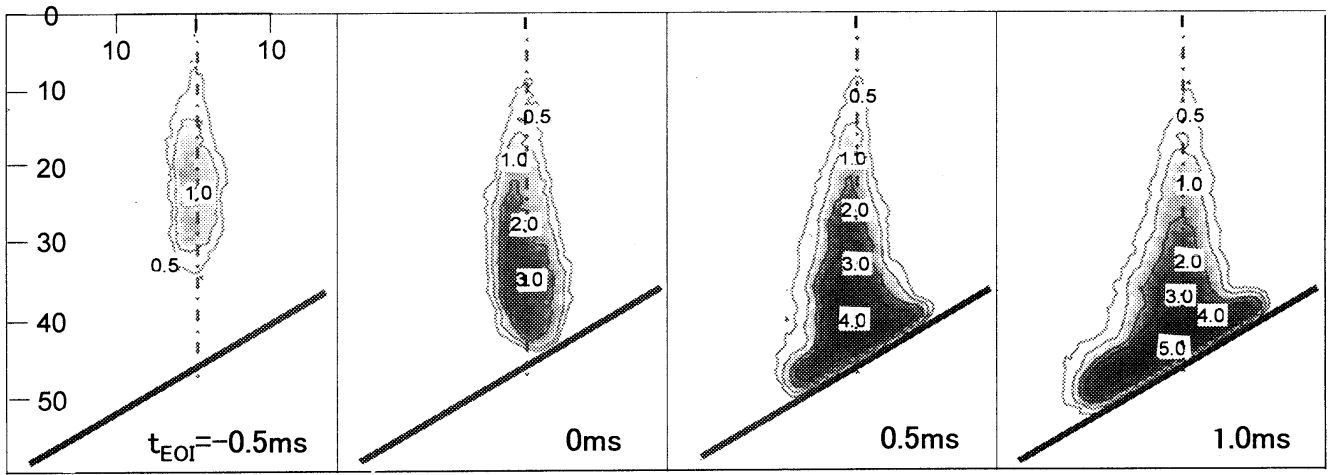

(c) $D_{\text {imp }}=45 \mathrm{~mm}, \theta_{\text {imp }}=60^{\circ}$

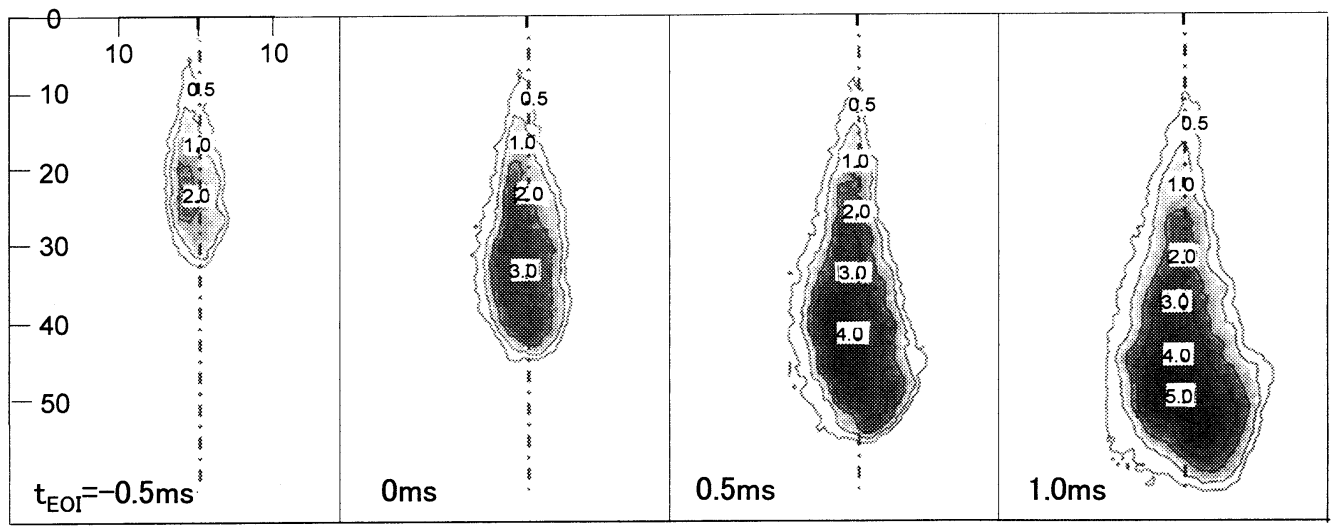

(d) Free spray (without impingement wall)

Fig. 8 Vapor phase mass distributions of wall impinging sprays and free spray 
小さくなっていることから, 壁面衝突後の噴霧先端到 達速度は自由噴霧よりも小さくなっていることが分か る. 衝突距離 $\mathrm{D}_{\mathrm{imp}}=45 \mathrm{~mm}$ では, 衝突直後の噴霧先端到 達距離が不連続に増加する (噴霧の幅が加わる : 図 6 の噴霧先端到達距離の定義による）ため, 噴霧先端到 達速度は同等となっているが，十分な時間経過後は $\mathrm{D}_{\mathrm{imp}}=15,30 \mathrm{~mm}$ と同様な傾向になるものと推測される.

5 -4 燃料蒸気相質量 図 10 に壁面衝突噴霧およ び自由噴霧の蒸気相質量の時間的変化を示す. 噴射期 間中 $\left(\mathrm{t}_{\mathrm{EOI}}<0\right)$ の噴射量は噴射率一定として求めた。蒸 気相質量のグラフは平板に噴霧先端が到達するまで (before WI: Wall Impingement, 黒シンボル) と, 衝突 した後 (after WI, 白シンボル) に分けてプロットして いる.

壁面衝突噴霧と自由噴霧を比較すると，いずれの衝 突距離でも衝突噴霧の方が蒸気相質量は小さくなって おり, 壁面衝突により然料の蒸発が抑制されている.

また衝突距離が短いほど蒸気相質量が小さくなってお り，蒸発がより抑えられていることが分かる.

図 11 に $t_{\mathrm{EO}}=1.0 \mathrm{~ms}$ 時の蒸気相質量と衝突距離の関係を 示す. 衝突距離 $D_{i m p}=60 \mathrm{~mm}$ 亡自由噴霧 $\left(D_{\mathrm{imp}}=\infty\right)$

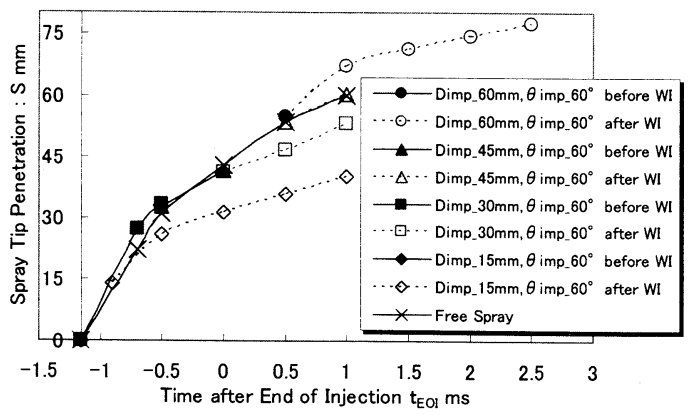

Fig. 9 Spray tip penetration

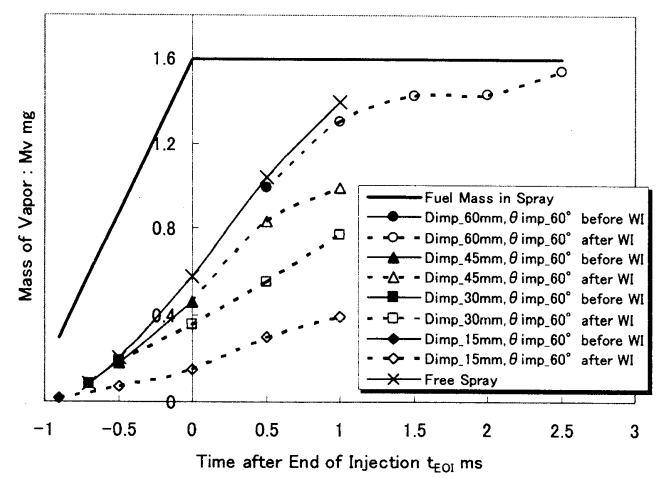

Fig. 10 Temporal variations of total mass of vapor in spray

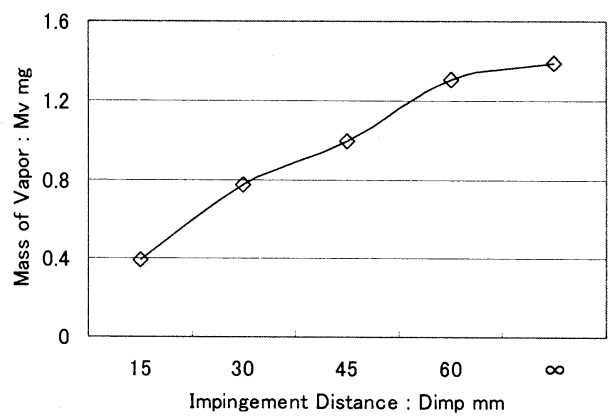

Fig. 11 Effect of impingement distance on total mass of vapor in spray at $\mathrm{t}_{\mathrm{EOI}}=1.0 \mathrm{~ms}$

では, 噴射量の約 $80 \%$ の燃料が蒸発しているのに対し， Dimp=30mm では約 50\%, Dimp=15mm では約 25\%し か蒸発していないことが分かる.

噴霧中の燃料が蒸発するためには，噴霧への高温の 周囲気体の取り込みが必要である. 壁面衝突により噴 霧先端およひ壁面側からの周囲気体の流入が抑えられ ることで，蒸発量が少なくなったのではないかと考え られる.

\section{6. 結 論}

新たに開発した非軸対称噴霧用の二波長レーザ 吸収散乱（LAS）法を用いて, 高温高圧下で平板 壁面に衝突する燃料噴霧の蒸気相質量の計測を行 った. 衝突角度 (噴孔軸と平板の角度) を $60^{\circ}$ 一定, 衝突距離（ノズル先端から壁面までの距離）を $15 \mathrm{~mm}-60 \mathrm{~mm}$ と変化させた範囲で, 以下のことが 明らかになった。

(1)非軸対称噴霧用 LAS 法と軸対称噴霧用 LAS 法を比較して見積もった非軸対称噴霧用 LAS 法の 誤差は約 $13 \%$ である.

(2)壁面衝突の無い自由噴霧と比べて, 同一時刻 における壁面衝突噴霧の噴霧先端到達距離が短く, 蒸気相質量が小さい. すなわち壁面衝突により燃 料の蒸発が抑制される。これは噴霧先端到達距離 の減少による噴霧先端からの䨌囲気取り込みの減 少, また, 壁面衝突後の壁面側からの雾囲気導入 が無くなることによると推察される.

(3)衝突距離が小さくなるほど, 同一時刻におけ る燃料噴霧内の蒸気相質量は小さくなる.すなわ ち壁面衝突による燃料の蒸発抑制がより顕著にな る.

今後, 非軸対称の完全蒸発噴霧を対象として, 燃料噴射量とLAS 法により求めた蒸気相質量の比 較による非軸対称噴霧用 LAS 法の計測精度を確認, 
次いで衝突角度の影響について解析を行う予定で ある。

\section{謝 辞}

本研究を遂行するにあたり,マツダ（株）から燃 料噴射装置の提供を受けた。また実験において, 広島大学大学院工学研究科博士課程前期の洲本康 樹氏および哈強氏の助力を得たことを記し，謝意 を表す。

\section{文献}

(1) Honda, T., Kawamoto, M., Katashiba, H., Sumida, M., Fukutomi, N., Kawajiri, K., A Study of Mixture Formation and Combustion for Spray Guided DISI, SAE Paper, 2004-01-0046 (2004), pp.1-9.

(2) Kawamoto, M., Honda, T., Katashiba, H., Sumida, M., Fukutomi, N., Kawajiri, K.,, A Study of Center and Side Injection in Spray Guided DISI Concept, SAE Paper, 2005-01-0106 (2005), pp.1-10.

(3) Seto, M., Yamashita, H., Ota, N., Murakami, Y., Yoshida, H., Spray Guided DISI using Multihole Injector, JSAE Transaction, Vol.37 No.4, (2006-7), pp. 101-106

(4) Steeper, R., Zilwa, S.D., Improving the NOx-CO2 Trade-Off of an HCCI Engine Using a Multi-Hole Injector, SAE Paper, 2007-01-0180 (2007), pp.1-14.

(5) Stach, T., Schlerfer, J., Vorbach, M., New Generation Multi-hole" Fuel Injector for Direct-Injection SI Engines-Optimization of Spray Characteristics by Means of Adapted Injector Layout and Multiple Injection, SAE Paper, 2007-01-1404 (2007), pp.1-15.

(6) Nouri, J.M., Mitroglou, N., Yan, Y., Arcoumanis, C., Internal Flow and Cavitation in a Multi-Hole Injector for Gasoline Direct-Injection Engines, SAE Paper, 2007-01-1405 (2007), pp.1-19.

(7) Koike, M., Mixture Formation and Combustion in Direct Injection Gasoline Engines, Technical Journal R\&D Review of Toyota CRDL, Vol.33, No.4, (1998-12)

(8) Chang, W., Kim, Y., Kong, J., Design and Development of a Central Direct Injection Stratified Gasoline Engine, SAE Paper, 2007-01-3531(2007), pp. 1-8.

(9) Li, T., Nishida, K., Zhang, Y., Hiroyasu, H., Effect of Split Injection on Stratified Charge Formation of Direct Injection Spark Ignition Engines, International Journal of Engine Research, Vol.8, No.2, (2007-4), pp. 205-219.

(10) Yamakawa, M., Takaki, D., Li. T., Zhang, Y., Nishida, K., Quantitative Measurement of Liquid and Vapor Phase Concentration Distribution in a D.I. Gasoline Spray by the Laser Absorption Scattering (LAS) Technique, SAE Paper, 2002-01-1644 (2002), pp.1-13.

(11) Kanzaki, J., Sato, K., Yamakawa, M., Nishida, K., Li, T., Zhang, Y., Spray and Mixture Characteristics of Hole Nozzle for D. I. Gasoline Engine, Proceedings of 13th ILASS Japan, 2004, pp. 233-238.

(12) Sato, K., Kanzaki, J., Yamakawa, M., Nishida, K., Comparison of Mixture Formation Process between Swirl and Hole Nozzles for DISI Engine, Proceedings of 14th ILASS Japan, 2005, pp. 109-114.

(13) Kamimoto, T., Ahn, S.K., Chang, Y.J., Kobayashi, H., Matsuoka, S., Measurement of Droplet Diameter and Fuel Concentration in a Non-Evaporating Diesel
Spray By Means of An Image Analysis of Shadow Photographs, SAE Paper, 840276 (1984) 